\title{
Green Energy in the Caribbean: Influence on Tourism and Economic Development
}

\author{
Zielona energia na Karaibach: \\ jej wpływ na turystykę i rozwój gospodarczy
}

\section{Tatiana Tazikhina*, Vladimir Kvasha**, Yulia Solovova**, Igbal Guliev****}

*Financial University under the Government of Russian Federation, Department of Corporate Finance and Corporate Governance, 49, Leningradsky Prospekt, Moscow, 125993, Russian Federation

E-mail: TTazikhina@fa.ru,ORCID:0000-0002-3763-4213

**Financial University under the Government of the Russian Federation, Yaroslavl branch, Kooperativnaya st., 12A, Yaroslavl, Yaroslavl region, 150003, Russian Federation

E-mail:VKvasha@fa.ru,ORCID:0000-0003-2929-9010

***MGIMO University, International Institute of Energy Policy and Diplomacy,

76, Prospect Vernadskogo Moscow, 119454

E-mail: yulia.solovova@gmail.com,ORCID:0000-0002-4555-0618

****MGIMO University, International Institute of Energy Policy and Diplomacy,

Address: 76, Prospect Vernadskogo Moscow, 119454, Russian Federation

E-mail (Corresponding Author): guliyevia@bk.ru,

ORCID: 0000-0002-8667-8132

\begin{abstract}
The green energy agenda has become one of the most important issues in international relations. Many island states of the Oceania have taken the course of green economy construction. The Caribbean states are in some way similar to the Oceania ones and have also made several steps towards greener future. Some of these states are tightly connected with international tourism, leading to the high dependence of their economies from touristic revenues. The article examines this interconnection, including economic component in the analysis. The major question of the article is how does (or doesn't) tourism influence the development of green energy in the Caribbean states. The two major economies examined in the region are Cuba and Dominican Republic as the two examples of the totally different economic systems and approaches to the development of the green energy. The key findings of the article include such conclusions as the possibility of synergetic interdependence between tourism, economy and green energy and the positive effects this interdependence has. The other finding is that the Cuban method of introducing green energy is less effective than the Dominican one. The novelty of the article includes the comparison of the two economic models in the Caribbean and the development of strategies for the green energy proliferation in the countries.
\end{abstract}

Key words: Caribbean, Cuba, Dominican Republic, green energy, strategy, barriers, drivers

\section{Streszczenie}

Agenda zielonej energii stała się jedną z najważniejszych kwestii w stosunkach międzynarodowych. Wiele wyspiarskich stanów Oceanii przeszło na kurs budowy zielonej gospodarki. Państwa karaibskie są w pewien sposób 
podobne do krajów Oceanii i również poczyniły kilka kroków w kierunku bardziej ekologicznej przyszłości. Niektóre z tych państw są ściśle powiązane z turystyką międzynarodową, co prowadzi do silnego uzależnienia ich gospodarek od przychodów $\mathrm{z}$ turystyki. W artykule przeanalizowano to powiązanie, uwzględniając $\mathrm{w}$ analizie komponent ekonomiczny. Głównym pytaniem artykułu jest to, w jaki sposób turystyka wpływa (lub nie) na rozwój zielonej energii w krajach karaibskich. Dwie główne gospodarki badane w regionie to Kuba i Dominikana jako dwa przykłady całkowicie odmiennych systemów gospodarczych i podejść do rozwoju zielonej energii. Do kluczowych ustaleń artykułu należą takie wnioski, jak możliwość synergicznej współzależności między turystyką, gospodarką i zieloną energią oraz pozytywne skutki tej współzależności. Drugim wnioskiem jest to, że kubańska metoda wprowadzania zielonej energii jest mniej skuteczna niż dominikańska. Nowością artykułu jest porównanie dwóch modeli gospodarczych na Karaibach oraz opracowanie strategii proliferacji zielonej energii w tych krajach.

Slowa kluczowe: Karaiby, Kuba, Dominikana, zielona energia, strategia, bariery, czynniki sprawcze

\section{Introduction}

The Caribbean sea is a very attractive region for tourism, as it provides the major components of the touristic attractions - it has the beautiful nature, rich history since the Spanish conquest of the region, the developed touristic infrastructure and significant potential in the all-year-round tourists arrivals (Sole, 2021). All in all, the region consists of 25 countries and 3 territories, but the major touristic attraction centers are Cuba and Dominican Republic (Sole, 2021). The attention in this article is concentrated on them, as the other countries of the region are less representative in the sphere of green energy development and tourism.

Tourism is known as one of the energy intensive industries, especially taking into account the service character of the industry. As a result, tourism has the high impact on the demand for energy in the countries, which generate the majority of their profits from touristic activities, such as the Caribbean ones. The green energy agenda and the responsibility in energy efficiency and greenness are significant influence factors on every industry, and taking into account the recent growth of the public concern on green energy, this sphere needs to become more energy efficient in case it wants to preserve its current position in the economy of the countries, depending on it.

In addition to the mentioned economic effects, both tourism and green energy can be analysed from the view of sustainable development. The UN Sustainable Development Goals (SDGs) provide the basis for the greener future, especially in the sphere of energy, and are obviously aimed at the more sustainable and effective development of the national economies. In this regard, sustainability is the important factor, which includes both tourism and green energy development, hence the article encompasses sustainability issues too. The SDGs in general sense give recommendations on the actions to be taken by the countries in order to achieve the UN Agenda, but this document doesn't give region specific recommendations, which is necessary for the more effective development of the countries. The article is devoted to the formulation of these region specific recommendations, based on the framework, given in UN SDGs.
The two countries have different economic systems and different approaches to the green energy development - while Cuba is a command economy with the high influence of industries on the economy of the country, Dominican Republic (DR) is a market economy with extremely high influence of tourism on the economy, and the developed services sector. As a result, the approaches to the development of the green energy in the two countries differ a lot. While Cuba forces its industries to the green energy transition by combining price and command methods (Martínez, 2020), DR follows the economic trends and sticks to the idea that tourism has the opportunity to control the economy of the country because of its high influence on it, hence the green energy transition is conducted under the pressure of tourism requirements (Goffi, et al. 2020). The article aims at revealing the major characteristics of the green energy development models of the two countries and figuring out the extent interdependence of the countries in the Caribbean region. This allows to give conclusions and recommendations on the further development of the green energy in the region in whole and in the named countries in particular.

The major finding of the article is the proof of the possibility of interconnection between the green energy development and tourism through economic and social benefits.

\section{Literature review}

The literature on the green energy development in the Caribbean can't be named vast. Many of the works cover the region partially, only touching its problems. For instance (Ahmed, Shimada, 2019) covers several regions and states, that the Caribbean states have to depend on conventional energy sources. The other paper (Singh, Ephraim, 2016) states that green energy is the new key agenda for the Caribbean, but has several major issues, such as finance, technology and sustainability in the local weather conditions. The work (Shah, Niles, 2016) focuses on the Caribbean in general and gives interesting institutional solutions, especially in the context of the partnership of the Caribbean states, but misses out the fact that this leads to the dangers for the island states' own policy and national security. 
At the same time, the other work (Mundaca, Markandya, 2016) states that the current state of being is far from the one to be achieved in order to comply with the green agenda goals. When speaking of Cuba, the only paper found in Scopus on the relevant theme id (Lorente, et al. 2020) which lies in the basis of the analysis, given hereinafter. The other article (Donastorg, 2020) gives major conclusions, used hereinafter for the DR, the assessment of the feed-in tariffs, mentioned later is given in (Jacobs, et al. 2013).

The overall conclusion on the sources on the green energy transformation in the Caribbean is their national orientation (each source mainly covers the situation in one country) and lack of comparative analysis on the development of green energy in the countries of the region. In this regard it's necessary to compare the green energy development models in the region and put forward propositions on each of the revealed models.

\section{Methodology}

The article is based on the following logic process. First of all, the authors search for the drivers of the green energy development in the countries researched. Such drivers bear economic and social character, then these drivers are weighted by the barriers, the character of which differs and can be political. Based on these drivers and barriers, the authors put forward a characteristic of the green energy development model of the country by the following parameters: a) the character of green energy transition, b) the economic basis of green energy development, c) the legal basis of green energy development, d) the social influence of green energy, e) the overall driver/barrier ratio. The last is calculated by the simple formula:

$D B R=Q d / Q b$

where $\mathrm{Qd}$ and $\mathrm{Qb}$ is the quantity of drivers and barriers. Thus, the overall complexity of the sphere can be estimated in figures.

The second step of the research is to provide crossvariable correlation analysis. This allows to figure out is the development of green energy in the country autonomous from other spheres or it has interconnections with them and synergetically develops with them. The analysis of correlation is based on the correlation formula:

correl $=\frac{\sum\left(x-m_{x}\right)\left(y-m_{y}\right)}{\sqrt{\sum\left(x-m_{x}\right)^{2} \sum\left(y-m_{y}\right)^{2}}}$

where $\mathrm{x}$ and $\mathrm{y}$ are the two variables, $\mathrm{m}_{\mathrm{x}}$ and $\mathrm{m}_{\mathrm{y}}$ are the means of the variables.

If the correlation is high $(>0,9)$ the interdependence is strong, if average $(0,5<$ correl $<0,9)$ then moderate, if low $(<0,5)$, then there is no interdependence. The cross correlation includes the analysis of two correlation values at the same time. If both of them are high or average, there is intercorrelation and synergetic effect is present, if not, the opposite is true. Based on the performed analysis the authors provide strategies, based on either synergetic effect of the three variables, or on the supposition of linear development of green energy in the country.

\section{Cuban model of green energy development}

The development of green energy on Cuba has begun in the 2005, but the framework for its further development was given only in 2014 when the country adapted a new Green energy plan (Alberto ArrastíaAvila, Glidden, 2017). The major decisions of this paper are discussed in the named source, so we won't concentrate on them here. As a result, the green energy industry in Cuba is one of the most rapidly growing in the Caribbean. At the same time, we can't avoid mentioning, that Cuba is forced to seek new sources of energy, as the conventional ones are too expensive.

The development of green energy in the country is stimulated by the following major drivers:

1) High price for the conventional energy resources. The country imports oil and gas from Venezuela (Cederlöf, Kingsbury, 2019), and this import is a rather expensive one. The average customer on Cuba spends 125-140\$ a month on electric energy (Yao Zhao, 2017), taking into account the low disposable income of the citizens of the country, this figure influences the social situation significantly.

2) The need to create a stable energy system. Due to the high volume of tourists and the high revenues of the state budget from their visits to the country, Cuba has to provide the best touristic experience possible, which is impossible in the current conditions of the unstable energy grid and high energy prices. In this paragraph it's necessary to mention that Cuba has less problems with energy infrastructure construction than Dominican Republic, as the territory of the latter is more exposed to the natural disasters because of the small territory of the island. In addition to that, the high share of the military infrastructure on Cuba along with the urge to preserve the constant function of the force institutions, such as the police, makes the development of the green infrastructure, based on the wellprotected infrastructure of the military character easier. The other important factor is the relatively big territory of the island and longer electricity lines, and higher share of industry in the GDP of the country, which contributes to the other infrastructure structure, making it less diversified and more centralized.

3) The necessity to preserve the national security. The country depends from imports of the energy resources, that's why it needs to secure itself from the market volatility and from the political 
pressure on the exporters, taking into account the long-run political tensions with the USA, a major influencer in Latin America, Caribbean and South America (Kaláshnikov, Kodzóev, 2018; Arazoo, 2013).

4) The abundancy of the natural riches, that are to be preserved. Clean air and water are necessary for the future development of the island, especially taking into account tourism. But even with no regard to this economic sphere, green agenda is extremely important for any island state, as it can't neglect the bad ecology because of the small territory and no way to recover the previous state of being without extremely big financial losses.

5) Excellent natural conditions for the green energy introduction. Cuba is one of the sunniest places on Earth, has the potential for wind energy generation and has already developed a sustainable system of the bioenergy production, especially in the field of fuel for vehicles and small powerplants.

All these drivers lead to the current situation, when Cuba forces the development of its green energy industry to comply with the ambitious goal of $24 \%$ of renewable energy in energy balance by 2030 . Still, there are several barriers for the development of green energy in the country:

1) The two-currency tariff. The country has two official currencies - the convertible Peso and the Cuban Peso, hence the monetary system of the country is rather complicated (Fernandes, 2018). This causes the issue of the foreign trade with Cuba in energy sphere - the tariffs are collected in Cuban Pesos, so how are they to be converted in convertible Pesos?

2) The significant legal issues with private property. In many developed countries of Europe green energy has started from the private initiatives in green energy development. How will Cuba manage to coordinate plan economy and private initiative? The issue is very important, as the rapid growth of green energy production in Europe started from the private sector, but transformed into general initiatives on the EU level, aimed at economic stimulation through the methods of green financing and green energy development. Hence, the green energy has become an institutional issue. In the plan economy the only way an initiative can become institutional is the convergence of the centrally planned actions and positive social attitude towards them. The Cuban issue is that the government can be less supported by the society than it supposed.

3) Lack of financial resources. Cuba has little or no possibilities to attract the financial resources from the developed countries and isn't a member of the international financial institutions. The major investor in the green energy of the country is China (Steve Hanley, 2017), so will the investments from PRC be enough for the sustainable development of Cuba?

In addition to that, the country is isolated from the international technological markets, which leads to the ability of Cuba to develop the green energy infrastructure, based on the local technologies. The low quality of education (Margarita, 2011), followed by the high barriers for the educated workforce to leave the country for the professional development lead to the lack of human capital and the significant issues with the technology development in the country.

In addition to that, the maintainable of the already existing infrastructure is rather weak because of the same reasons. The major difference of the maintenance of the green energy infrastructure from the maintenance of the road infrastructure for instance, is the need for qualified personnel and the high standards of quality, which Cuba lacks.

The overall lack of resources in Cuba makes the development of green energy in the country a matter of high importance, but little prospects for international help and cooperation. The country has to rely on its own.

These barriers form significant problems for the future development of the Cuban energy industry, based on the green energy, so the country has to solve them in order to comply with the national green energy development plan.

The overall characteristic of the Cuban model of green energy is that it is a forceful model, the economy of the country is forced to conduct green energy politics in order to avoid severe losses, green energy is developed centrally, no private initiatives are present, the legal basis is rather not developed and bears a character of statements, green energy has moderate social influence, but it's not enough for the massive public support. At the same time, the DBR equals to 1,66 , pointing on the high potential for the green energy development in Cuba.

\section{Dominical green energy development model}

DR is another center of tourism in the Caribbean. But it has another model of green energy development than the one, Cuba has. Green energy development in the country is regulated by the Law 57-07 (IRENA, 2016), which regulates the major spheres of green energy use in the country.

At the same time, nearly $60 \%$ of the demand for energy in the country is supported by hydrocarbons' imports. The major drivers, leading to the development of the green energy in the country are the following:

1) High prices for the hydrocarbons. Just as in Cuba, the country faces severe problems with the imports of hydrocarbons.

2) The excellent natural conditions for the green energy generation. The abundancy of sun and 
wing make the best possible conditions for the green energy production.

3) The growing energy market. The active tourism and the industrial development of the island leads to the necessity to develop new ways of energy production, especially taking into account the high burden of conventional energy production costs.

4) The availability of external financial resources for the green energy development in Dominican Republic. DR doesn't have technologies for green energy development, but its partners, such as the USA and EU do, and taking into account the good economy development forecasts (Reyes, Useche, 2019) and the tight relationships with the finance donor countries, DR can have a cheap and fast introduction of green energy technologies in the next years.

5) The necessity to create a green environment for the development of tourism. The territory of the country is smaller than the one of Cuba, but the tourist inflow and the demand for energy from the industry is significant, which leads to the faster degradation of the natural environment, than the one on Cuba. In addition to that, the high influence of the marine transport on the environmental conditions of the country force it to introduce stricter regulations and higher energy standards in order to preserve the major source of the budget - tourism revenues.

These are the main drivers for the development of the DR energy market, but there are several barriers too:

1) The legislative framework is still quite misty. The Law 57-07 has to be extended in the sphere of attracting investments in the green energy sphere and stimulating private initiatives. In addition to that, it's necessary to make the system of the energy regulation easier, as today there are discussion on who controls the development of the energy system of the country (Alexander, et al. 2015).

2) The energy grid of the country is rather weak. The current energy grid isn't suitable for massive green energy production due to the lack of two-way exchange possibilities (The Economist, 2015). The other important issue is the lack of energy storage facilities, which are quite expensive and require high investments in security and ecological safety - the leakage of heavy metals from the batteries can cause significant damage to the water resources and wildlife of the nearby region. In case such leakage happens massively (for instance, because of the malfunction due to the bad weather conditions, or human factor, including terrorist attacks, the damage to the nature of the island will be significant.

3) The necessity to prove the effectiveness of the current measures to the population. The current green energy transfer is to be supported by the private initiatives of the population, otherwise it won't have the planned effect. Today the population of the country isn't secure of the future of green energy in DR, so the support to such initiatives is rather low.

In addition to the mentioned, the necessity to provide a secure and stable source of energy will lead to the inevitable overkill in energy supply of the Dominican Republic. In case of the intense international trade in energy this will lead to a higher export values of the country, but in case of the Caribbean, where the overall density of international electricity network is very low, the international trade in energy is unlikely. In case the international trade in energy model doesn't work for the country, the extensive production facilities will cost significant amounts of financial resources, but their return on investments will be low or even negative. This leads to the growth of costs of green energy transfer in the country and to the ineffective use of the acquired investments in the sphere. Due to the barriers mentioned earlier, the ineffective use of financial resources will lead to the low outcomes of the green energy transformation in the country.

The other important factor to mention is the regular character of the natural disasters. Taking into account their devastating nature, the construction of the green energy infrastructure should be based on the principles of the defense of the first from the negative impacts, which will rise the costs of infrastructure construction significantly. In addition to that, the storages of energy, which are represented by batteries of different kinds, should be protected from water, which will add on the costs of the green energy development.

This is a significant problem, as the main consumers of energy in the country are tourist facilities, which are located majorly on the coast, which is affected most significantly by the natural disasters.

The overall characteristic of the Dominican green energy development model is the following. Green energy in DR develops because of the need from the private and public sector, based on the market demand for the more efficient energy source, the legal framework is developed, despite the need for modernization and provides enough opportunities for the green energy initiatives, the social influence of the green energy is moderate to high, because of both cheaper energy and higher incomes from tourism. The overall DBR equals 1,33, demonstrating a high potential for future green energy sector growth.

The assessment of the interconnection of tourism, economic development and green energy in the countries

The interconnection between tourism and energy sector comes from the high demand for energy in tourism. This, in turn, happens because of the ineffective spending of the energy resources by the tour- 


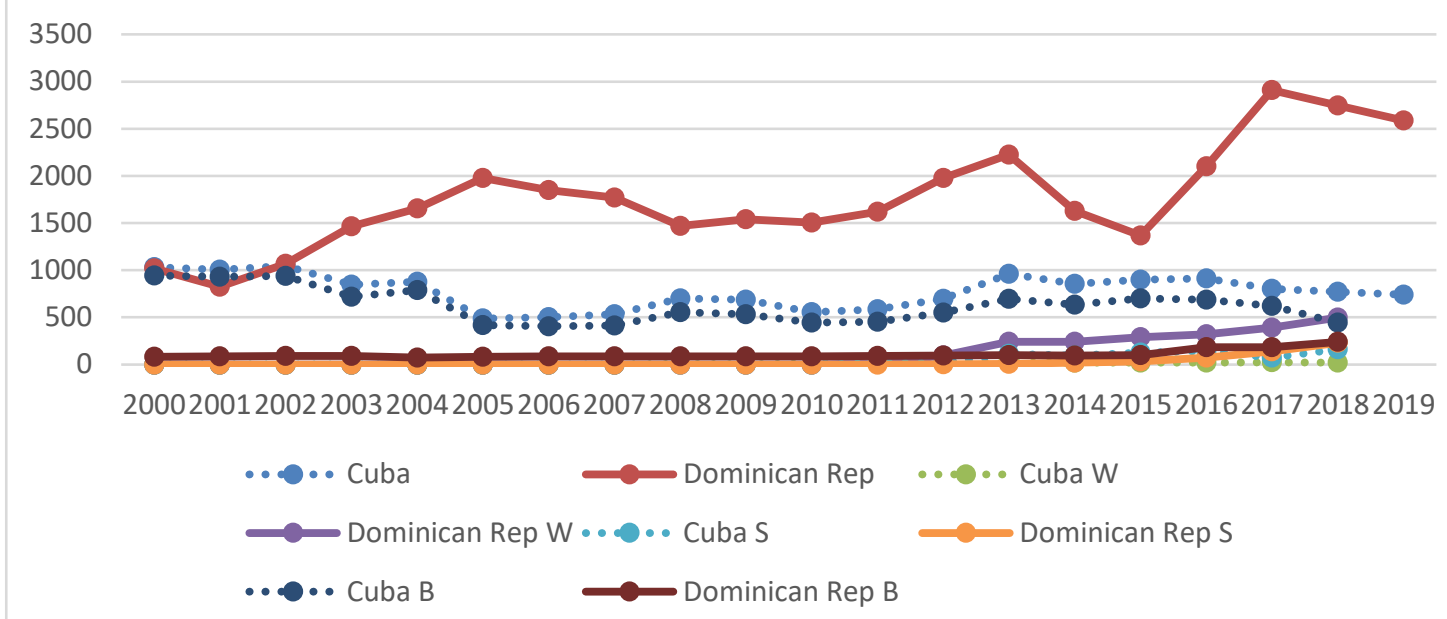

Figure 1. Green energy production by sources ( $\mathrm{w}$ - wind, $\mathrm{s}$ - solar, $\mathrm{b}$ - bioenergy), GWh, created by authors, based on (IRENA, 2018).

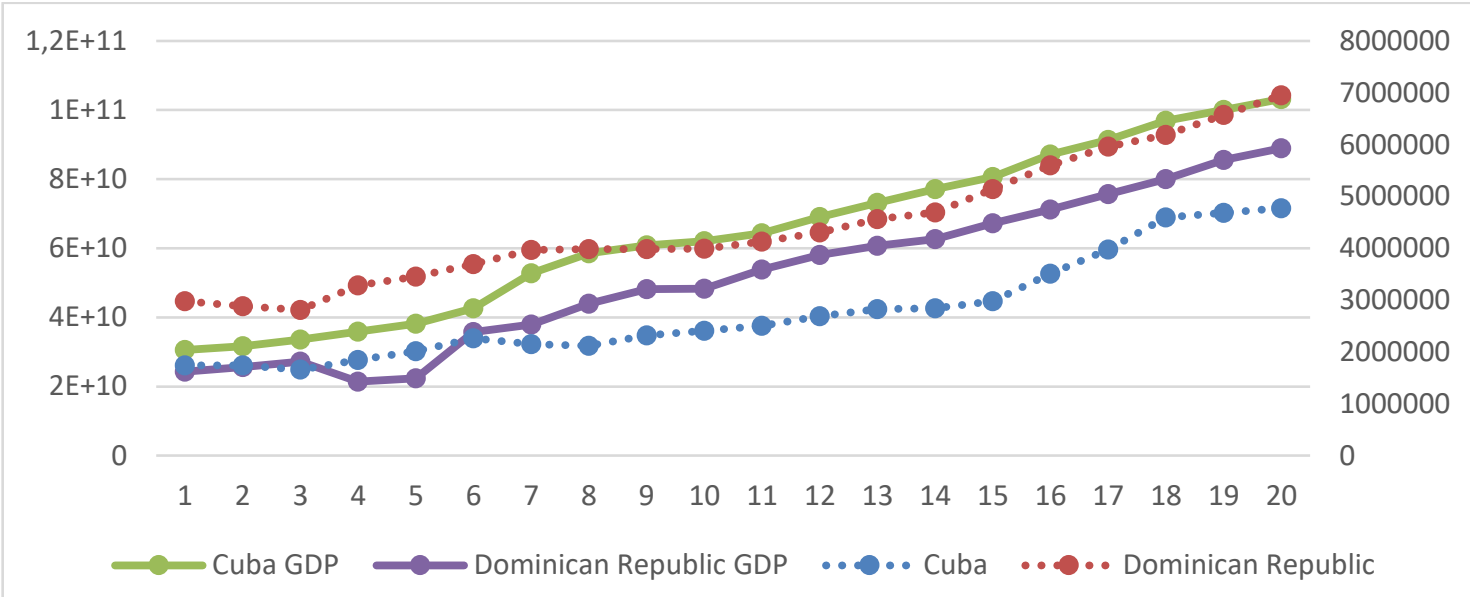

Figure 2. GDP and tourist arrivals in the countries, US\$ and persons, created by authors, based on and (The World Bank, 2019).

ists and by the touristic infrastructure, aimed at the fulfillment of the wishes of tourists, which are chaotic and hardly predictable with high preciseness. The optimization of energy consumption in this regard is nearly impossible.

In order to figure out the interconnection between tourism and green energy production, lets refer to the green energy production trends in both countries, presented on Figure 1.

The data on figure 1 demonstrates the substitution of bioenergy in Cuba by the solar energy and the significant influence of the hydroenergy on the energy balance of Dominican Republic. The other important notice is that Cuba has less developed green energy sector than DR, despite having similar ambitious plans. We observe a rapid growth of solar energy use in DR, just as in Cuba and quite humble growth of wind energy.

This effect can be a result of technical limits of the use of wind energy, for instance, wind generators produce noise, they are rather big and spoil the landscape and their maintenance requires higher quality specialists and is more expensive than the one of the solar panels, especially when they are mounted in private sector, where their maintenance lies entirely on the costs of citizens, who installed them.

The decrease in the biofuels use in Cuba can be connected with the gradual modernization of the vehicle park of the country, and their higher fuel efficiency. As a result the demand for biofuels from the automobile sector falls, while the demand for them from the electricity generation facilities hasn't grown yet because of the time lag and a not clear economic efficiency of their use in the sector.

Let's refer to figure 2, depicting GDP growth of the countries and the number of tourists arriving.

Figure 2 demonstrates a stable growth of GDPs of the countries and a stable growth of tourists flow to Cuba with a slowdown in DR. This situation reflects the tendencies in the product life cycle, referring to the necessity to modernize the touristic infrastructure and services in DR.

The interconnection between the three variables can be assessed through the correlation analysis, presented in table 1 . 
Table 1. Correlation analysis $(\mathrm{t}-$ tourism, $\mathrm{c}-$ green energy capacity, $\mathrm{p}-$ green energy production, $\mathrm{e}-\mathrm{gdp})$

\begin{tabular}{|l|l|l|l|l|}
\hline & T/C & T/P & T/E & P/E \\
\hline Cuba & 0,6941363 & $-0,02364217$ & 0,941187624 & $-0,12276587$ \\
\hline Dominicana & 0,9365757 & 0,809388595 & 0,964191028 & 0,745754726 \\
\hline Total & 0,79919613 & 0,767337754 & 0,559399201 & 0,062930561 \\
\hline
\end{tabular}

The table is colored according to the correlation strength. As a result of the correlation analysis, we have come to the following results:

1) Tourism influences the economy of both countries significantly, as it provides high financial benefits for the countries' budgets. The Caribbean region economy is moderately affected by tourism.

2) Tourism has a significant impact on the green energy production in DR, but no impact on the Cuban green energy. Its impact on the overall green energy development in the Caribbean region is moderate.

3) Tourism has a very high impact on the green energy capacity in DR, while its impact on the same parameter in Cuba and in the Caribbean is moderate.

4) Only DR has the direct connection between tourism, economy and green energy production, while Cuba and the Caribbean region don't have it.

The results of the correlation analysis prove the fact, that the Dominican model of the economic development and the green energy framework is much more effective in terms of green energy production than the one in Cuba. The changes in DR come from the private initiative, while Cuba relies on the state regulation and has no social framework, suitable for the sustainable green energy development.

In the current conditions of COVID-2019 pandemic tourism suffers a lot. Both countries have faced negative effects of this situation, but when referring to EU, pandemic has given the boost for the green energy development. In the Caribbean COVID-2019 has led to a significant restoration of the wildlife due to the lower quantity of tourists, but the green energy sector has faced no significant boosts. This has happened due to the fact, that in the EU the recovery program is based on the EU Green Deal, involving the green energy financing, when in Cuba and Dominican Republic such programs haven't been introduced.

\section{Discussion}

As it follows from the results, the Cuban model of green energy development doesn't provide synergetic effect nor has it from the economy or tourism, while the Cuban economy depends on tourism. The Dominican republic has the synergetic effect, so the proposed strategy of green energy development for it can be based on measures, connected with tourism.
In this regard, we propose the following strategy for the greener energy sphere in DR.

The first step is to enhance the legal framework of green investments. As we have mentioned above, the Law 57-07 doesn't stimulate foreign investments to the necessary extent. The major possibilities in this sphere are the following: a) the tax reform in order to provide tax benefits for the foreign investors in the green energy projects, b) the concretization of the green energy projects characteristics and the formation of the basic principles of the green finance, c) the government stimulation of the private initiatives in the green energy sector by both taxes and subsidies, d) the development of the long-run plan for the green energy development for a period from 2030 to 2050.

The second step is the cooperation with the international institutions and investors, for instance, the creation of the Dominican Green Energy Investment Fund, based on the bilateral agreements with the international companies and institutional investors.

Tthird step is the modification of grid. In order to do that, the country can attract the financial support from the World Bank Group or from the other development banks, for instance, the New Development Bank of BRICS or the Interamerican Development Bank.

The fourth step is the promotion of green energy production among the citizens of the country by using the special tariffs and returns for the ones, who sell energy to the grid.

The fifth step is the creation of the extensive tourism revenues fund, which can be used to promote green energy development in the country by financing the local projects in the most tourism attractive zones. In addition to that, the fund can be used for the modernization of touristic infrastructure and making it greener.

The sixth step is to develop and promote internationally the new way of tourism - the green tourism. The main way to do that is to form the major principles of zero carbon trace and zero nature influence of such kind of tourism and assess the concrete tours in accordance with such principles. These principles are to be introduced for hotels, transfer, excursions and food, so if the tour complies with these characteristics, the tourist can apply for a partial refund of tour price when leaving the country. The promotion of such tours is to be organized on international level through touristic agencies.

The seventh and one of the most important steps is to create a clear framework for the ESG institutions 
and initiatives. In this context it's necessary to develop a system of indicators for the green finance development, especially for the green bonds. This will allow to attract new financial resources to the country, especially form the countries, which are highly involved in the green transformation, such as the EU countries and the USA, taking into account the green energy plan of Biden 9 (Fulton, 2020).

Taking into account the will of Dominican Republic to develop the green energy infrastructure, it is a good idea to join the initiate of zero-plastic and zerowaste society and tourism. It will contribute to the overall decrease of the hydrocarbon-active industries, especially those, which involve polymers production. In turn, this step demonstrates the high involved ness of the country in the green initiatives, attracting new investors and green institutions to the country. When speaking of green institutions, it can be a significant attractiveness factor to introduce zero taxes for the institutions, which are of green character (this step involves the prior development of the standards for the green institutions). As a result the coverage of the Dominican green initiatives will be much better and the country will be able to attract more investments in the green energy.

This strategy will lead to the high openness of the country to foreign initiatives in the sphere of green energy and will be able to provide new possibilities for the local entrepreneurs, aimed at the green energy development.

When speaking of Cuba, the country can't boast the synergetic effect of economy for green energy. The strategy for its development of green energy is the following.

The first step is to encourage the private initiative in this sphere. In order to do that, the country can apply special energy tariffs for those, who produce green energy, the special trade tariff policy, which will stimulate the imports of the cheap green energy facilities' components, etc. The stimulative measures like subsidies aren't to be applied as the misuse of the financial resources is highly possible.

The second step is the tight partnership with those countries, which can support the Cuban energy sphere. For now, it's China, which provides massive investments in Cuban green energy for political reasons first of all.

The third step is to boost the production of biofuels for the needs of electricity generation. At the current stage, the major consumer of biofuel in Cuba is the automobile sector, so in order to boost green energy, the Cuban government should introduce the double tariff for fuel - the lower one for biofuel electricity generation and the higher one for automobile owners.

The fourth step is promotion of green energy among the citizens, so they can support the development of the sector both financially and by volunteering.

The fifth step is to develop the major guidelines for the industry. One of the major industries in Cuba is the tobacco industry (Wikle, 2015) which has been generating a significant inflow of capital to the country. In the era of massive green energy transformation, the new strategy for the greener energy in the country is the gradual transfer of tobacco industry to the green energy, or the introduction of compensations tax for the industry in case it refuses to comply with the new standards of the greener energy and new technologies of cleaner future.

As a result of introduction of such strategy, Cuba can have a significant growth in green energy development in the next 5-7 years due to the formation of the tight bond between the social importance of the green energy development and its economic effects.

\section{Conclusion}

The development of green energy in the two countries is a very difficult goal, which needs weighted, but rapid decisions. The analysis of the green energy sphere in Cuba and Dominican Republic allows to figure out the two major paths pf the green energy development in the Caribbean.

The first path is the Cuban one, which is proved to be less effective. It's the path from the central power to the local decisions. This path is less effective due to the issues with the financial regulation on Cuba, the difficulties with private property and private initiatives realization and the unclear future of the private projects on the island. The other negative side is the lack of external financial resources and the low availability of financial mechanisms for the green energy development.

The second path is the Dominican one. It includes the numerous market initiatives, the dependency of green energy development on tourism and the significant inflow of capital from foreign investors. It's based on the clear regulative framework and provides guaranties for the investment in the green energy.

The Dominican path also has a significant bonus the development of green energy is synergetic with tourism and economic development. In this regard, the process of greening the energy sphere of the country will go automatically in case the country economy grows and the inflow of tourists rises too. Based on these two paths and the barriers, put forward by authors, the strategies of the green energy development were formed. These strategies use the synergetic effect for DR and aim at the structuration of the Cuban chaotic green energy initiatives. The results of these strategies' implementation are higher, if the measures, mentioned in them are taken in complex.

The authors have proved that in the Caribbean green energy can be interconnected with tourism and the development of one can boost the other, but in order this to be true, such interconnection is to be based on the economic and social benefits, that the countries and their population can receive from green energy. 


\section{References}

1. AHMED, M.M., SHIMADA, K., 2019, The effect of renewable energy consumption on sustainable economic development: Evidence from emerging and developing economies, Energies, 12(15): 2954.

2. ARRASTIA-AVILA A., GLIDDEN M., LISA M., 2017, Cuba's Energy Revolution and 2030 Policy Goals: More Penetration of Renewable Energy in Electricity Generation, International Journal of $\mathrm{Cu}$ ban Studies, 9(1): 73-90.

3. FEROZAN A., 2013, The Impact of the American Influence on the Economic and Political Development of the Caribbean: Case Study of Puerto Rico and Cuba, https://core.ac.uk/download/pdf/235683277. pdf (5.04.2021).

4. CEDERLÖF G, KINGSBURY D.V., 2019, On PetroCaribe: Petropolitics, energopower, and post-neoliberal development in the Caribbean energy region, Political Geography, 72: 124-133.

5. COLE S., 2021, Innovation, Competitiveness, and Sustainability in Tourism Clusters: An Empirical Model of Caribbean Destinations, Regional Science Perspectives on Tourism and Hospitality. Advances in Spatial Science (The Regional Science Series, eds. Ferrante M., Fritz O., Öner Ö., Springer, Cham, DOI: 10.1007/978-3-030-61274-0_19.

6. DONASTORG A., RENUKAPPA S., SURESH S., 2020, Evaluating critical success factors for implementing renewable energy strategies in the Dominican Republic, Renewable Energy, 149: 329-335.

7. FERNANDES, M.P., WEGNER, R., MARTINS, P., 2018, Aspects to understand the peculiar Cuban monetary system, Estudos Internacionais, 6(3): 118133.

8. FULTON M., EIS J., LING E., CRONIN D., 2020, The Inevitable Policy Response Under Biden's Climate Plan The Stage Is Set, https://www.unpri.org/ download?ac=12103 (5.04.2021).

9. GOFFI G., CLADERA M., OSTI L., 2020, Sun, sand, and... sustainability in developing countries from a tourists' perspective. the case of Punta Cana, Sustainability (Switzerland), 12(11): 4743.

10. HANLEY S., 2017, China Invests In Renewable Energy In Cuba, https://cleantechnica.com/2019/05/ 19/china-invests-in-renewable-energy-in-cuba (5.04.2021).

11. IRENA, 2016, Renewable Energy Prospects: Dominican Republic, https://www.irena.org/-/media/Files/ IRENA/Agency/Publication/2016/IRENA_Remap_ Dominican_Republic_report_2016.pdf (5.04.2021).

12. IRENA, 2018, Trends in Renewable Energy, https:// public.tableau.com/views/IRENARETimeSeries/Ch arts?\%3Aembed $=\mathrm{y} \& \% 3$ AshowVizHome $=$ no $\&$ publi $\mathrm{sh}=\mathrm{yes} \& \% 3$ Atoolbar $=$ no $\& \% 3$ Amobile $=$ true (5.04.2021).

13. JACOBS D., MARZOLF N., PAREDES J.R., RICKERSON W., FLYNN H., BECKER-BIRCK C., SOLANO-PERALTA M., 2013, Analysis of renewable energy incentives in the Latin America and Car- ibbean region: The feed-in tariff case, Energy Policy, 60: 601-610.

14. KALÁSHNIKOV N.V, KODZÓEV M.A.-M., 2018, From Obama to Trump: Transformation of the CubaUSA relations at the current stage. Iberoamerica (Russian Federation), 1: 24-49.

15. LORENTE A.G, LÓPEZ M.H., ÁLVAREZ F.J.M., JIMÉNEZ J.M., 2020, Differences in electricity generation from renewable sources from similar environmental conditions: The cases of Spain and Cuba, Sustainability (Switzerland), 12(12): 5190.

16. LÓPEZ Q.M., 2011, Education in Cuba: Foundations and challenges, Estudos avançados, 25(72): 55-71.

17. MARTÍNEZ J.L., 2020, The economic reform in cuba after the approval of the new constitution in 2019, Revista de Ciencia Politica, 40(2) 287-313.

18. MUNDACA L., MARKANDYA A., 2016, Assessing regional progress towards a Green Energy Economy, Applied Energy, 179: 1372-1394.

19. OCHS A., FU-BERTAUX X., KONOLD M., MAKHIJANI S., SHRANK S., ADKINS C., 2015, Roadmap to a Sustainable Energy System: Harnessing the Dominican Republic's Sustainable Energy Resources, Worldwatch Institute, https://www.sica. int/busqueda/busqueda_archivo.aspx?Archivo=dpro _71038_1_23072012.pdf (5.04.2021).

20. REYES G.E., USECHE A.J., 2019, Competitiveness, economic growth and human development in Latin American and Caribbean countries 2006-2015: A performance and correlation analysis, Competitiveness Review, 29(2): 139-159.

21. SHAH K.U., NILES K., 2016, Energy policy in the Caribbean green economy context and the Institutional Analysis and Design (IAD) framework as a proposed tool for its development, Energy Policy, 98: 768-777.

22. SINGH A., EPHRAIM J., 2016, Ocean energy: The new energy frontier for the Eastern Caribbean Small Island Developing States, Energy Policy, 99: 1-3.

23. THE ECONOMIST, 2015, The future of the electricity sector in the Dominican Republic, https://www. ces.org.do/images/2015/FunglodeElectricitySectorReportEnglishFINAL.pdf (5.04.2021).

24. THE WORLD BANK, 2019, GDP (current US\$), https://data.worldbank.org/indicator/NY.GDP.MKT P.CD (5.04.2021)

25. THE WORLD BANK, 2019, International tourism, number of arrivals - Cuba, https://data.worldbank. org/indicator/ST.INT.ARVL?locations $=\mathrm{CU}$ (5.04.2021)

26. WIKLE T. 2015, Tobacco Farming, Cigar Production and Cuba's Viñales Valley, Focus on Geography, 58(4): 153-162.

27. YAO Z., 2017, Power Shift in Cuba: Seven Reasons to Watch the Renewable Energy Sector in the PostFidel and Trump Era, Renewable Energy World, https://www.renewableenergyworld.com/baseload/ power-shift-in-cuba-seven-reasons-to-watch-the-renewable-energy-sector-in-the-post-fidel-and-trumpera (5.04.2021). 